\title{
IN MEMORIAM OF PROFESSOR PETRO F. GOZHIK, ACADEMICIAN OF THE NATIONAL ACADEMY OF SCIENCES OF UKRAINE
}

\section{СВІТАОЇ ПАМ'ЯТІ АКААЕМІКА НАН УКРАЇНИ ПЕТРА ФЕОАОСІЙОВИЧА ГОЖИКА}

\author{
Vyacheslav M. Shestopalov, Oleksandr M. Ponomarenko, Stella B. Shekhunova \\ В. М. Шестопалов, О. М. Пономаренко, С. Б. Шехунова
}

Institute of Geological Sciences, NAS of Ukraine, 55-b 0. Honchara Str., Kyiv, Ukraine, 01601

(shekhun@gmail.com)

\begin{abstract}
Статтю присвячено пам'яті видатного українського вченого в галузі палеонтології, стратиграфії, морської геології, лауреата Аержавних премій України в галузі науки і техніки (1989, 2000), заслуженого діяча науки і техніки України (1997), лауреата премії ім. П. А. Тутковського НАН України (2008), Аиректора Інституту геологічних наук НАН України (1997-2020), презиАента Палеонтологічного товариства України, голови Національного стратиграфічного комітету України, ініціатора створення і першого Аиректора Національного антарктичного наукового центру (тоАі - Центру антарктичних АосліАжень НАН України), Аоктора геолого-мінералогічних наук (1993), професора (2008), академіка НАН України (2006) Петра Феодосійовича Гожика. Наукові інтереси Петра Феодосійовича були багатогранні, однак передусім він був видатним палеонтологом і стратиграфом, геологом-четвертинником, визнаним досліАником викопних прісноводних молюсків з неоген-четвертинних віАКлаАів півдня Східної Європи. Його роботи із стратиграфії четвертинних віАкладів, палеогеографії четвертинного періоду, історії розвитку континентальної частини Україні і Чорного моря у четвертинний час, вивчення четвертинних молюсків, континентальних

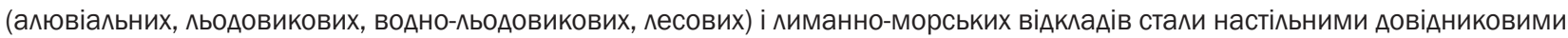
виАаннями.

Ключові слова: Петро Феодосійовича Гожик, стратиграфія, морська геологія, Інститут геологічних наук НАН України.
\end{abstract}

This article is devoted to the blessed memory of Petro F. Gozhik, prominent Ukrainian scientist in the fields of paleontology, stratigraphy, marine geology, Winner of the State Prizes of Ukraine in Science and Technology (1989, 2000), Merited Figure of Science and Technology of Ukraine (1997), Laureate of NAS Tutkovsky Prize (2008), Director of the Institute of Geological Sciences of the NAS of Ukraine (1997-2020), President of the Paleontological Society of Ukraine, Chairman of the National Stratigraphic Committee of Ukraine, initiator and the first Director of the National Antarctic Research Center (previously the Center for Antarctic Research of the NAS of Ukraine), Doctor of Geological and Mineralogical Sciences (1993), Professor (2008), Academician of the NAS of Ukraine (2006). Scientific interests of P. F. Gozhik were diverse, but, first he was an outstanding paleontologist and stratigrapher, Quaternary geologist, a renowned researcher of the Neogene - Quaternary fossil freshwater mollusks of the south of Eastern Europe. His works in Quaternary stratigraphy, paleogeography and the geological history of continental Ukraine and the Black Sea, the study of Quaternary mollusks, continental (alluvial, glacial, water-glacial, loess) and estuarine sediments became tabletop reference books.

Keywords: Petro F. Gozhik, paleontology, stratigraphy, marine geology, Institute of Geological Sciences National Academy of Sciences of Ukraine.

P. F. Gozhik was born on October 21, 1937, in the township of Goshcha - a district center of the Rivne Oblast (photo 1). After graduating from high school, he entered the Department of Geography of Chernivtsi State University (photo 2) and graduated from it with honors in 1959. His graduation thesis "Geomorphology and Quaternary deposits of the Kelmenetskyi and Sokyrnyanskyi districts of the UkrSSR" was highly praised and was noticed by Professor P. Zamoriy, a recognized expert in
Quaternary geology of Ukraine, who invited the talented student for post-graduate courses at the Department of Geomorphology of Taras Shevchenko State University of Kyiv.

After a year of work as the principal of Krasnovolsk school, P. F. Gozhik entered the postgraduate studies of the Institute of Geological Sciences (IGS) of the UkrSSR Academy of Sciences in 1960. From that time on, his life became inseparable from this scientific institution, where

Цитування: Шестопалов В.М., Пономаренко О.М., Шехунова С.Б. Світлої пам'яті академіка НАН України Петра Феодосійовича Гожика. Збірник наукових праць Інституту геологічних наук НАН України. 2021. Том 14, вип. 1. С. 5-16. https://doi.org/10.30836/igs.2522-9753.2021.228225.

Citation: Shestopalov V. M, Ponomarenko O. M., Shekhunova S. B., 2021. In memoriam of Professor Petro F. Gozhik, Academician of the National Academy of Sciences of Ukraine. Collection of scientific works of the Institute of Geological Sciences NAS of Ukraine. Vol. 14, iss. 1. Pp. 5-16. https://doi.org/10.30836/igs.2522-9753.2021.232269. 


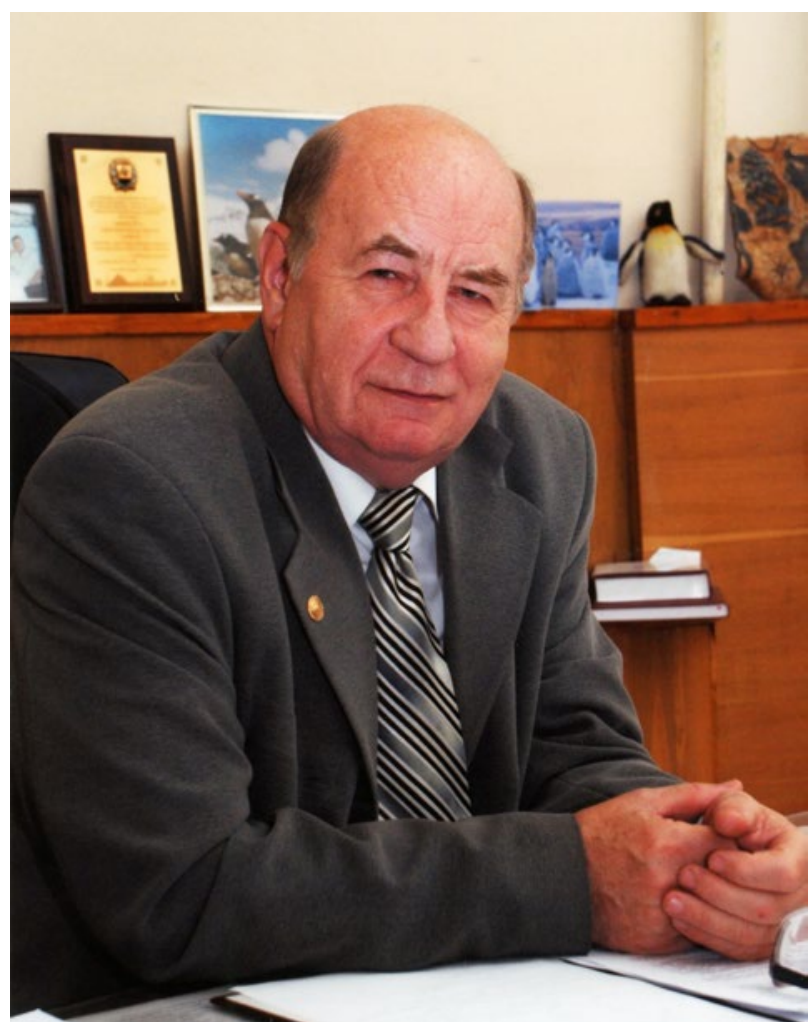

Photo 1. Petro Feodosiyovych Gozhik (21.10.1937-29.12.2020).

he at first continued his Quaternary geology research commenced in university, and then was systematically expanding the range of his scientific interests, which covered the problems of geology, stratigraphy, minerals of Ukraine, marine geology, and geoecology of Antarctica (Ponomarenko et al., 2017). At the Institute he was consistently promoted in his scientific and corporate careers: in 19601963 - a PhD student, in 1963-1974 - a junior researcher, from 1974 - a senior researcher at the Department of Geotectonics and Anthropogene Geology; from 1982 - the head of Institute's laboratory of geology and lithodynamics of the coastal zone; from 1986 - a leading researcher in the Department of Anthropogene Geology; from 1987 - the Deputy Research Director of the Institute, and from 1997 till the very end of his life on December 29, 2020, he held the position of the Director of the Institute of Geological Sciences of the NAS of Ukraine (photo 3).

The career advancement was preceded by scientific achievements. In 1966, under the guidance of Academician V.G. Bondarchuk, P. F. Gozhik defended his candidate (PhD) thesis "Geology and stratigraphy of the Prut River Valley terrace deposits" and got a Candidate's (PhD) degree in geological and mineralogical sciences. In

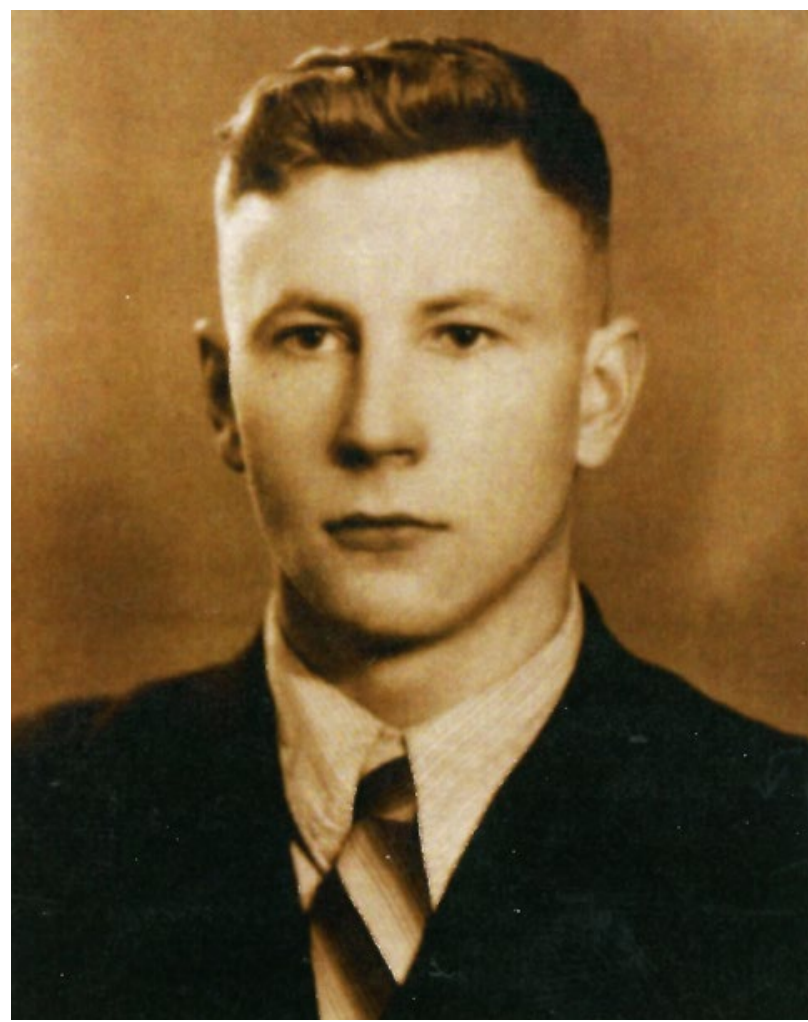

Photo 2. P. F. Gozhik, a second-year student of Chernivtsi University; 1956.

1992, he defended his doctoral thesis "Freshwater mollusks and the correlation of Upper Cenozoic alluvial deposits in the south of the East European Platform". From his very first steps in science, P.F. Gozhik was distinguished for his perseverance, courage in taking on new tasks, and the ability to combine solutions to scientific problems with practical issues. Having mastered a certain research direction or branch, he expanded the range of his scientific interests. His scientific passions included paleontology, freshwater fauna, geology and stratigraphy of Anthropogene and Neogene deposits (loess and glacial ones in particular), Cenozoic formations; marine geology, Antarctic research, biosphere geology, and geoecology; geology of minerals, especially hydrocarbon resources.

\section{Anthropogene Geology and Stratigraphy}

From the 1960s, P. F. Gozhik carried out extensive research of the alluvial deposits of Ukrainian rivers, which resulted in the first ever proposed scheme for the Prut River valley terraces and their correlations with the Dniester and the Danube terraces. These studies were accompanied by large-scale work for production enterprises during the geological survey of Ukraine and Moldova. The research of the Pivdennyi Bug and Ingulets river 


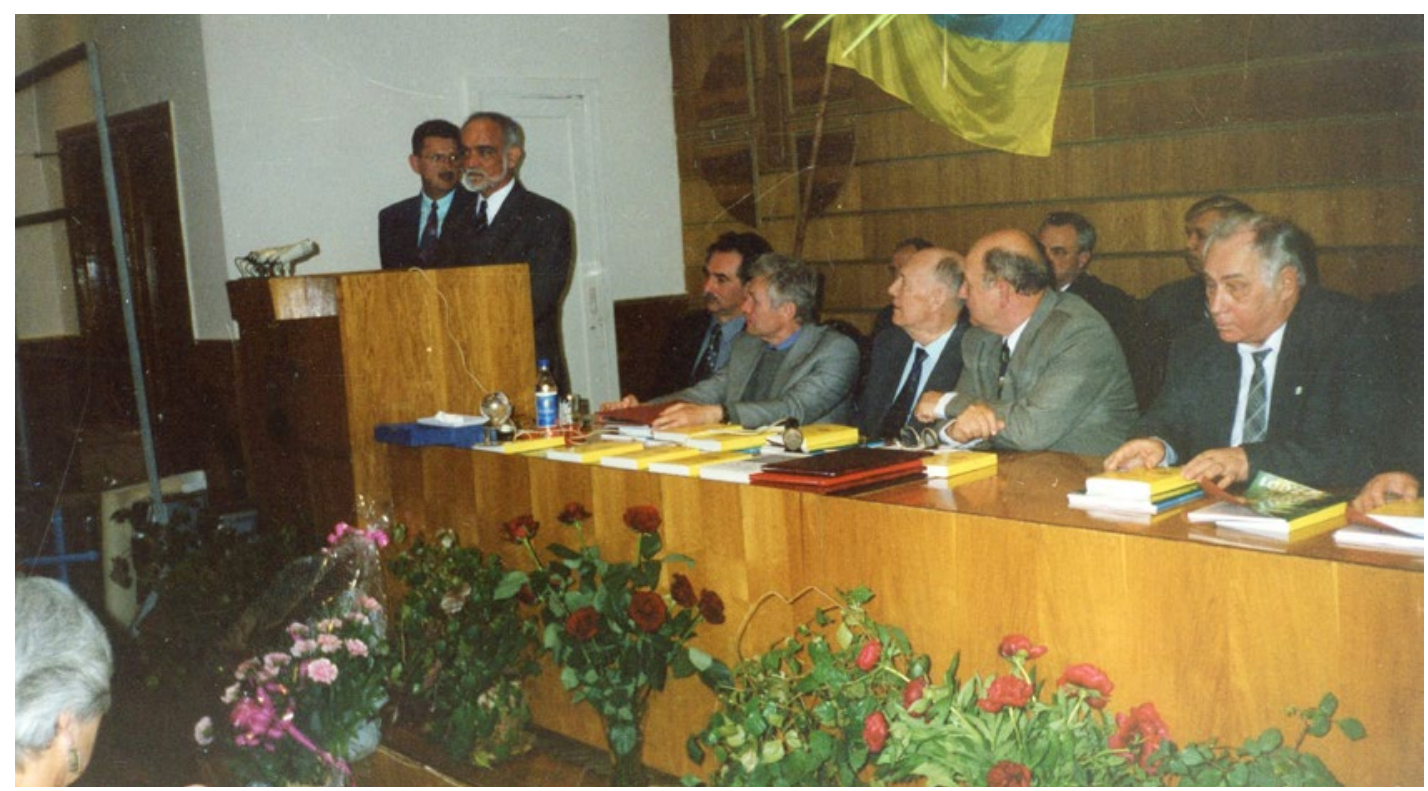

Photo 3. Hungarian colleagues congratulate on the 75th anniversary of IGS of the NAS of Ukraine. In the presidium (from left to right): S. V. Goshovskyi, First Deputy Chairman of the State Committee for Natural Resources of Ukraine; Academician V. I. Starostenko, AcademicianSecretary of the NAS Department of Earth Sciences; Academician B. E. Paton, President of the NAS of Ukraine; NAS Corresponding Member P. F. Gozhik, Director of IGN of the NAS of Ukraine; Academician E. F. Shnyukov, Director of the National Natural History Museum of the NAS of Ukraine; 2001.

alluvial deposits were initiated in connection with the mineral deposit survey.

The implementation of the program of expanding irrigation systems in southern Ukraine required the launch of large-scale hydraulic engineering construction projects, and, consequently, conducting comprehensive geological survey. P. F. Gozhik was actively engaged in it (photo 4-5). He analyzed the geological structure of the Neogene-Quaternary deposits of the Dniester - Pivdennyi Bug and Pivdennyi Bug Dnieper interfluves, lithodynamics of the coastal zone of the Danube - Dniester section to design the Danube - Dnieper Canal route and to produce geological feasibility report for the construction of the Dnieper - Bug hydroelectric power plant (Gozhik, Novoselsky, 1989). Those projects were not implemented, but the evidence obtained enabled scientists to deal with several issues of the geological structure of southern Ukraine, to conduct in-depth research into the structure of bottom sediment in estuaries, and to shed light on the history of their evolution (Garkusha, Gozhik. (eds), 1984; Moroz, Sulimov, Gozhik, 1995). Theoretical investigations became the basis for constructing the stratigraphic schemes, compiling paleogeographic maps, for engineering and geological generalizations. This stage of work was described in the following books: "Geology of the UkrSSR shelf. Estuaries" (1984), "The direction of coast evolution between the Dniester estuary and the Danube Delta" (1988), "Geological conditions of constructing the Dnieper - Bug hydroelectric power plant" (1989), "Geological structure of the Northern Black Sea” (1995).

Concurrently, extensive research was focused on loess and glacial deposits. P. F. Gozhik, as the head of organization and field trips bureau, demonstrated the outcomes of those investigations to the participants of the All-Union Conference on Marginal Glacial Sediments (Kyiv, 1976), the VIII International Loess Symposium (Kyiv; Odesa, 1976), and the XI International Quaternary Congress (Moscow, 1982) (Gozhik et al., 1976; Shelkoplyas et al., 1986). In the 1980s, close scientific relations with European researchers were established, which became the basis for the launch of Symposia on glacial and loess deposit studies (photo 7); the most recent of those - the 21st, was held last year in Ukraine (Gozhik et al., 1995; Gozhik et al., 2000, Gozhik, 2004, Lindner et al., 2005; Lindner et al., 2006). Summarizing works in this field were 


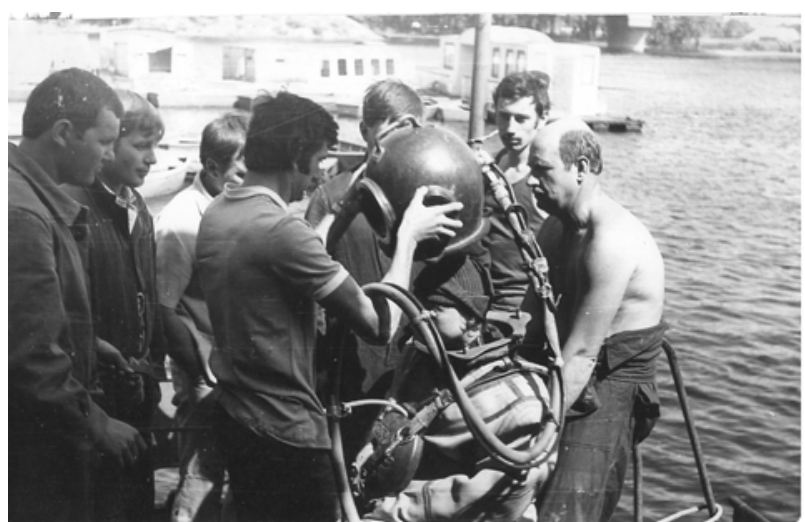

Photo 4. P. F. Gozhik is ready to submerge in heavy diving suit. Kyiv Maritime Divers School at DOSAAF; 1978.

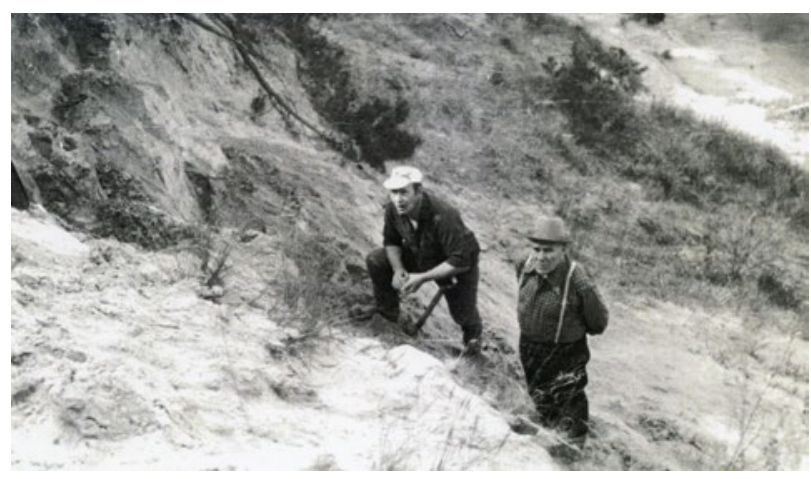

Photo 6. 5th all-Union Conference on studying the marginal formations of continental glaciation. Overview of the moraine's position within a coastal cliff with Academician G. I. Goretsky. Leliv, 1976.

the monograph "Correlation of loess and glacial deposits in Poland and Ukraine" (2000), as well as a series of papers with proceedings of INQUA symposia (Gozhik (ed.), 2000).

\section{Geology of oceans and seas}

From the 1970 s, P. F. Gozhik was actively engaged in multidisciplinary geological and geophysical research of oceans and seas at the IGS of the Academy of Sciences of UkrSSR. During expeditions to the Indian, Atlantic, and Southern Oceans, he was focused on the issues of lithology and stratigraphy of bottom sediments. In 1981, he headed the geological and geochemical expedition on the "Hydrologist" research vessel in the Red Sea (Gozhik et al., 1988). The results of those studies became the basis for the following collaborative monographs: "Geology and metallogeny of the northern and equatorial parts of the Indian Ocean" (1984), "Geology and metallogeny of the southwestern Red Sea" (1988) and "Geology and metallogeny of the tropical Atlantic" (1989).

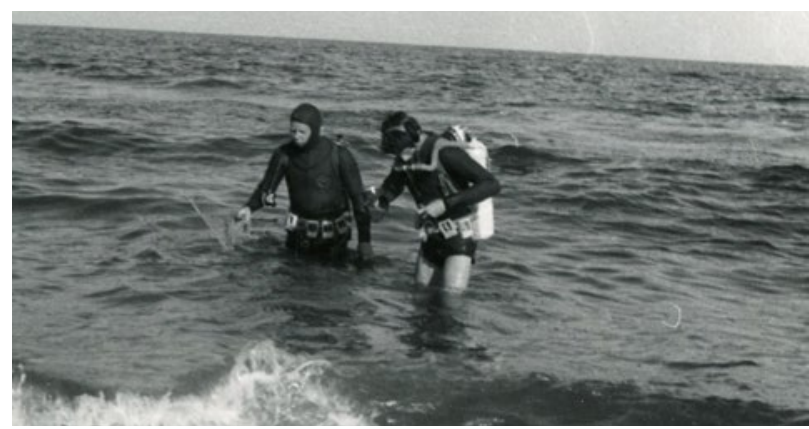

Photo 5. Pre-project geological survey for the feasibility study of the Danube-Dnieper channel route and development of the Dnieper-Bug hydroelectric power plant. After the inspection of underwater reference marks on the southern slope of the Budatsky Pass. The 1980s.
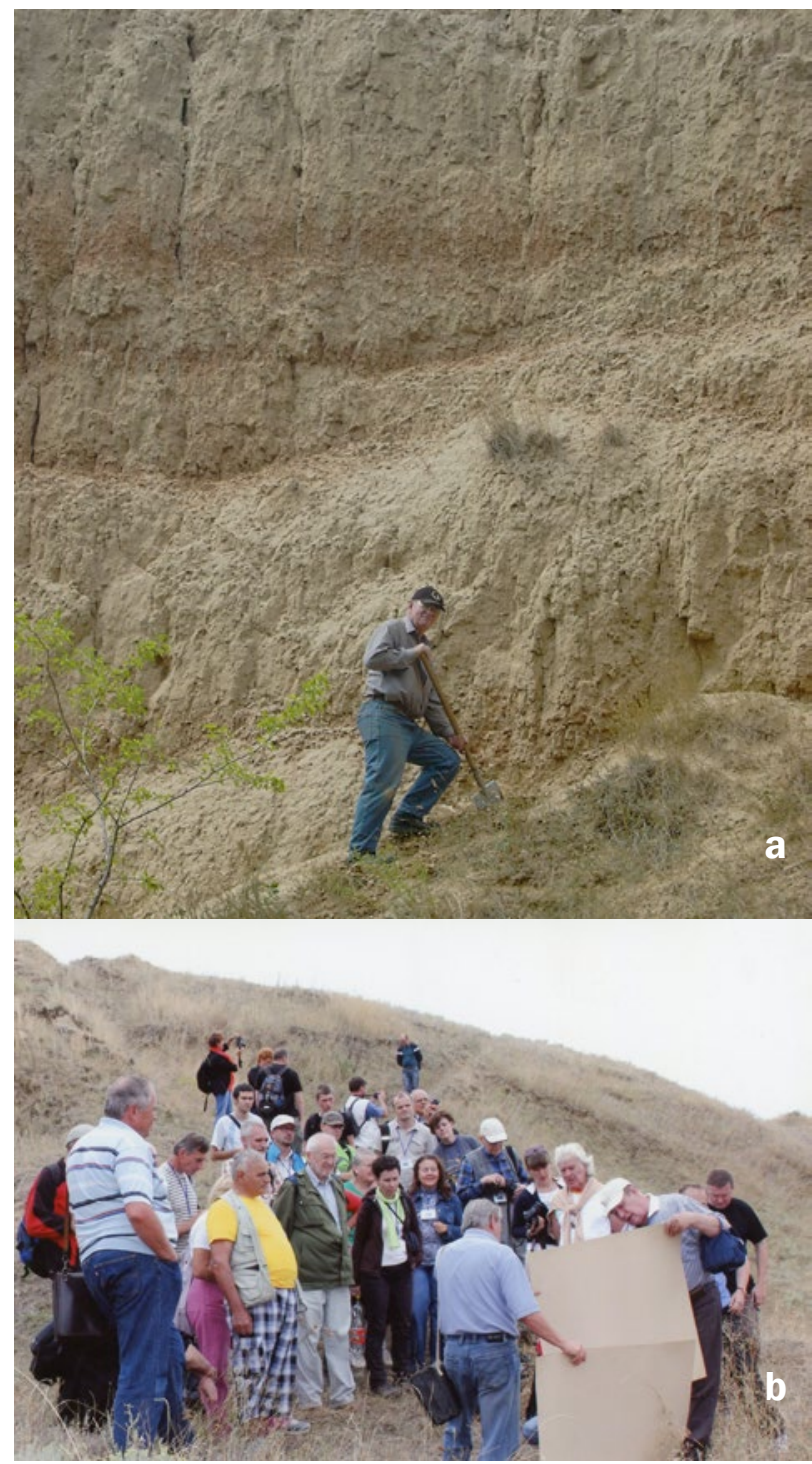

Photo 7. XVIII Ukrainian-Polish seminar "Loess cover of the northern Black Sea region". Preparation of the Roxolany key section for an international seminar (a); explaining the section's structure (b). Roxolany, 2013. 
A significant event was the circumnavigation Antarctic expedition (1982-1983) on "Thaddeus Bellingshausen" and "Admiral Vladimirsky" oceanographic research vessels of the Hydrographic Service of the Black Sea Fleet, where P.F. Gozhik was the geological team leader (photo 8-12). The expedition discovered new fields of ironmanganese concretions in the Southern Ocean and new longitudinal and transverse trenches on the Antarctic shelf (Gozhik P. F. et al., 1991, Ivanik, Gozhik, 2002). Subsequently, these results were discribed in the monographs "Geology and Metallogeny of the Southern Ocean" (1991) and "Geological and Geomorphological Studies of the East Antarctic Seas of the Southern Ocean" (2002). Back then, in the 1980s, the link that tied him with Antarctic problems was formed.

\section{Research of Antarctic}

However, most frequently the scientific community of Ukraine remember P. F. Gozhik, doctor of geological and mineralogical sciences, professor, NAS Academician as the long-term head of the oldest scientific geological institution of the country - the Institute of Geological Sciences of the NAS of Ukraine, which he headed longer than any of his predecessors - for twenty-three years from 1997 till 2020, and, besides, as the founder of Ukrainian research in the Antarctic.

He invested truly titanic efforts into organizing the first multidisciplinary Antarctic expeditions, and did a lot to ensure that the Ukrainian national flag was not just formally soaring over the distant island of Galindez, but that Ukraine joined the global Antarctic science as a full-fledged participant in the exploration of the far-away continent.

P. F. Gozhik was the founder and the first director of the Antarctic Research Center of the National Academy of Sciences of Ukraine. Now, the photos of signing on July 20, 1995, the Memorandum between the British Antarctic Service and the Center as a part of the Intergovernmental Agreement on the transfer by Great Britain of its Antarctic Station "Faraday" (later renamed to "Academician Vernadsky") to Ukraine are presented in national encyclopedias and textbooks as an important milestone in Ukraine's independence. Recalling those events, he always emphasized with respect and gratitude the essential role of B. E. Paton, President of the NAS of Ukraine, and Academician S.V. Komisarenko, the then Ambassador of Ukraine to the United Kingdom, without whose support and efforts Ukraine would hardly be presented in the Antarctic today. During the hard times of the USSR collapse and Ukraine regaining independence, the consistent and purposeful activities of the leadership of the NAS of Ukraine, Academicians S. V. Komisarenko and P.F. Gozhik towards the continuation of research in the Antarctic as an important and prestigious issue in terms of international scientific ranking and geopolitical subjectivity of our country and its future place on the geographic map of Antarctica, attracted many highly regarded people to this strategic idea and convinced the government of the necessity of its future development.

In 1992, Russia declared itself the successor to all the Antarctic stations of the Soviet Union and refused to transfer one of them to Ukraine. In February-August 1992, Academician P. F. Gozhik, with some other scientists and experts, sent letters of initiative and appeals to government agencies concerning the necessity for resuming and continuing the activities of Ukrainian scientists in Antarctica.

In 1993, P. F. Gozhik initiated the creation of the Antarctic Research Center of the NAS of Ukraine and became its first director, and in 1996 he became the head of the Ukrainian Antarctic Center of the Ministry of Science and Technology of Ukraine. In 1994, at a congress in Rome, the Antarctic Research Center of the NAS of Ukraine was admitted to the International Scientific Committee for Antarctic Research. On July 20, 1995, in London, S. V. Komisarenko, Ambassador Extraordinary and Plenipotentiary of Ukraine, signed the intergovernmental agreement, and P.F. Gozhik signed the Memorandum with B. Haywood, Director of the British Antarctic Service, on the transfer of the British Antarctic Station "Faraday" to Ukraine (photo 13).

On February 6, 1996, the British flag was lowered at the station and the Ukrainian flag was raised (photo 14). The first Ukrainian Antarctic Station named "Academician Vernadsky" appeared on the world map. Since then, Ukraine has belonged to the group of 30 Antarctic states.

Under the leadership of P.F. Gozhik, the first and the second multidisciplinary Ukrainian Antarctic expeditions were organized and the first State Program of Ukrainian Research in the Antarctic (1996) was developed. He was also actively working to develop the second and third research programs in the Antarctic. In 2010, he was appointed the scientific director of the National Antarctic Research 


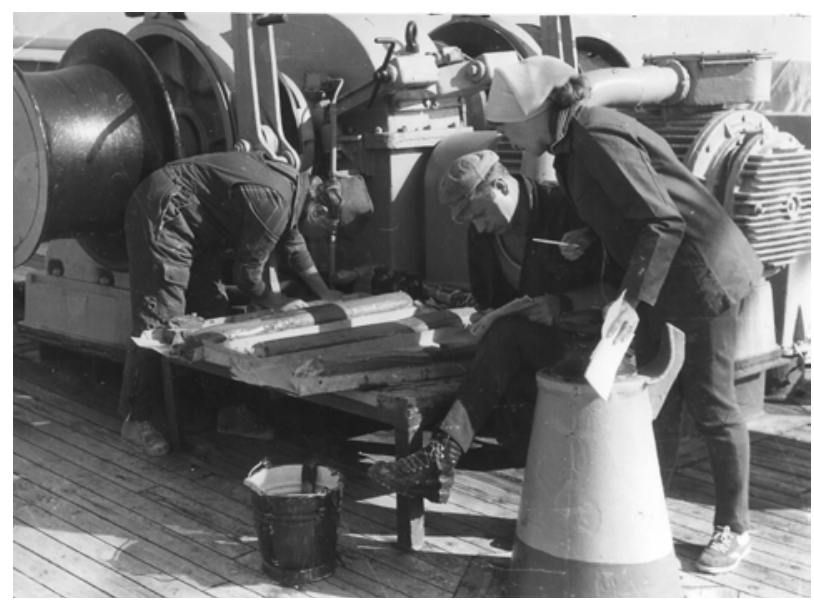

Photo 8. Description of the raised core sample column. The Black Sea expedition on the "Thaddeus Bellingshausen” hydrographic vessel; 1979.

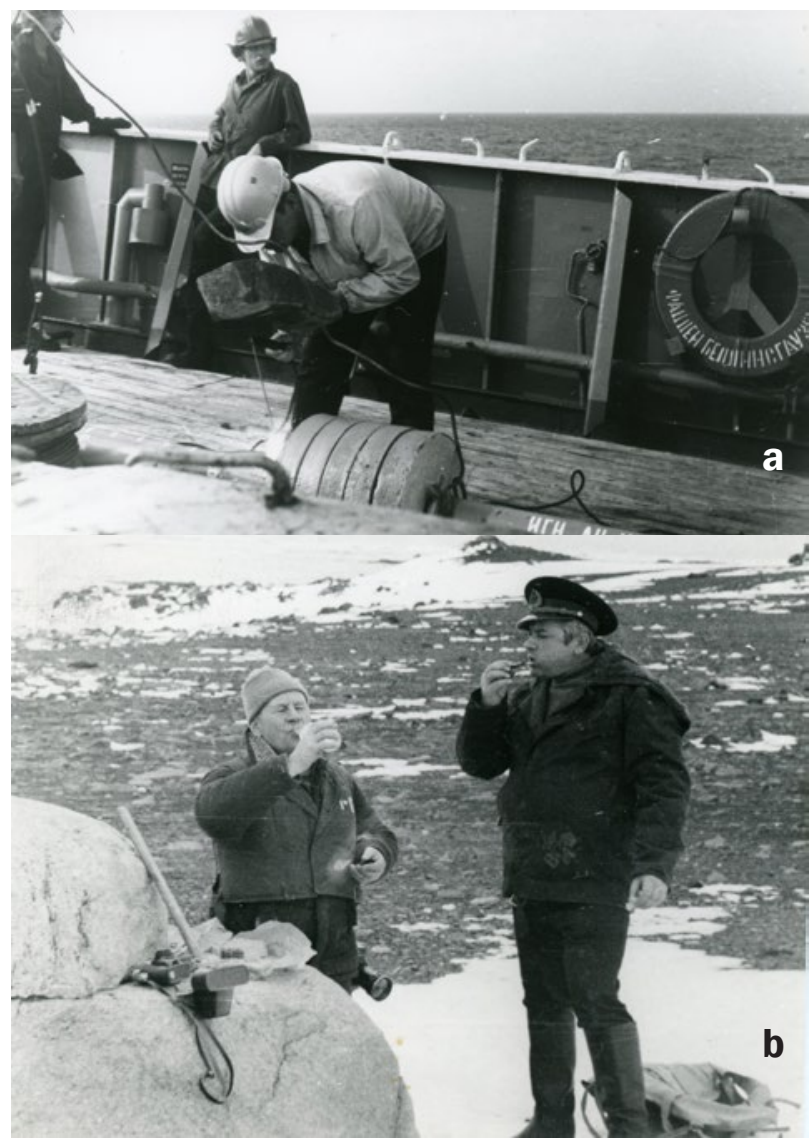

Photo 10. Around-the-world Antarctic expedition of the Navy on "Thaddeus Bellingshausen" and "Admiral Vladimirsky" oceanographic research ships: P. F. Gozhik performing welding repair of the soil-sampling tube (upper photo); the first breakfast on land on the Bellingshausen Sea shore. 1982-1983.

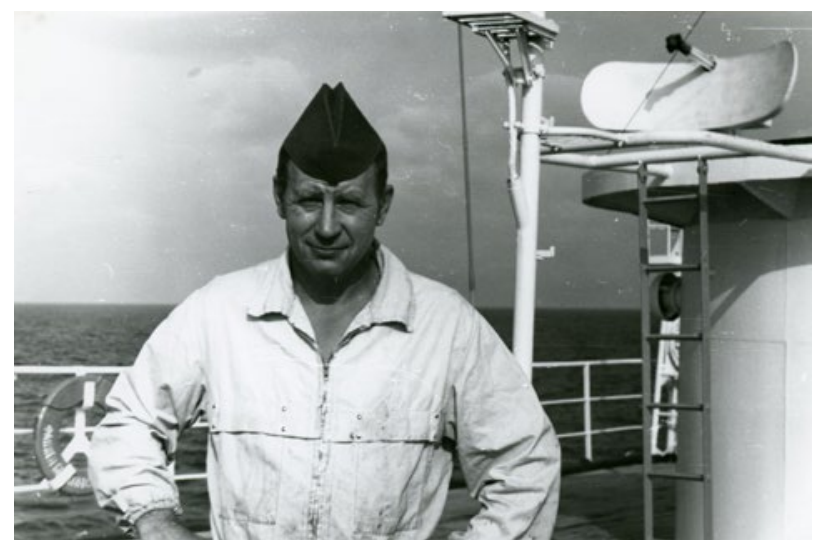

Photo 9. On deck. The Red Sea; 1981.

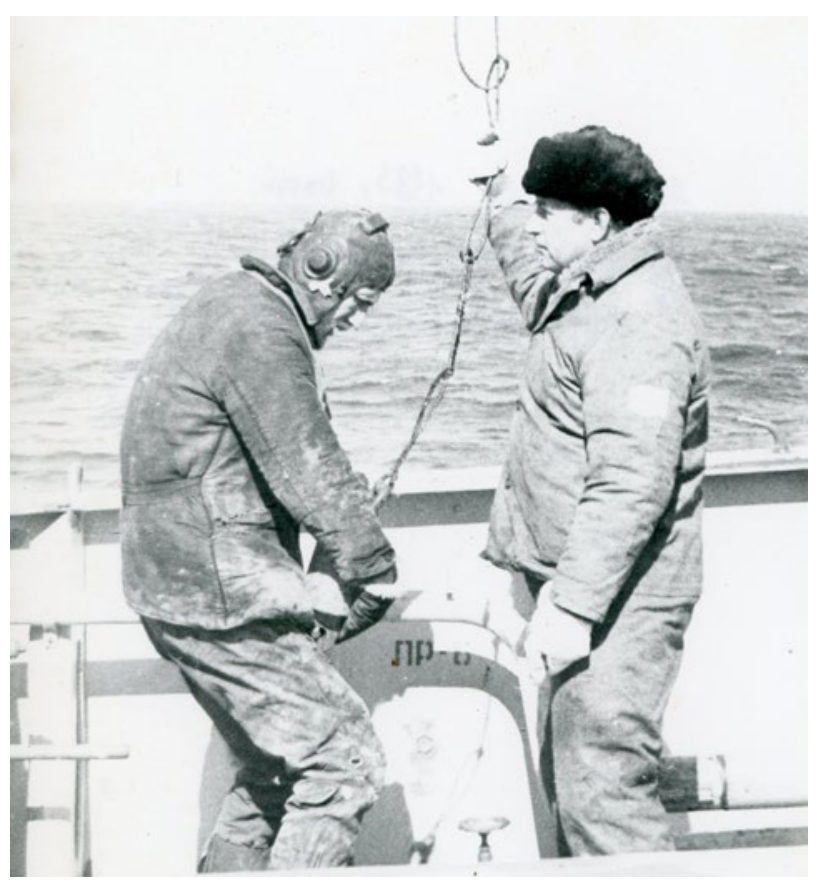

Photo 11. P. F. Gozhik and V.P. Vernigorov are preparing the bottom soil-sampling tube. The Bellingshausen Sea; 1983.

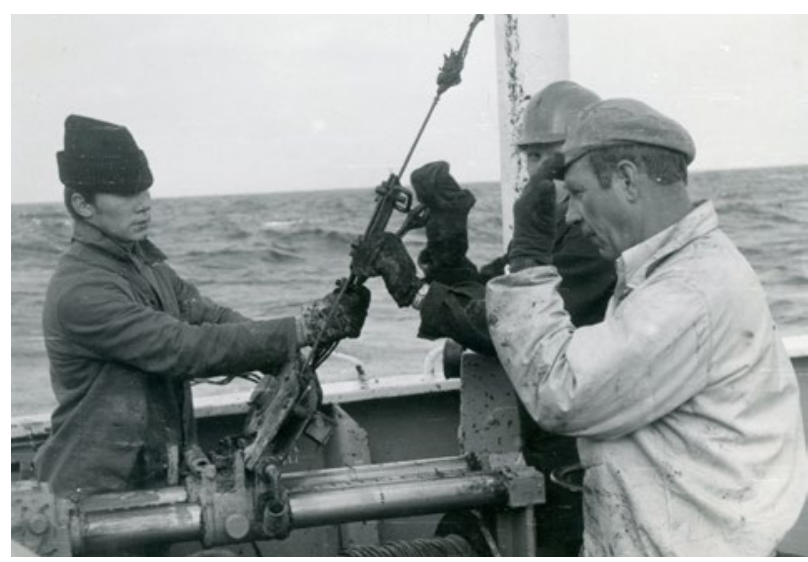

Photo 12. Preparation before the descent of the soil sampling tube in the Danube underwater canyon area; 1989. 


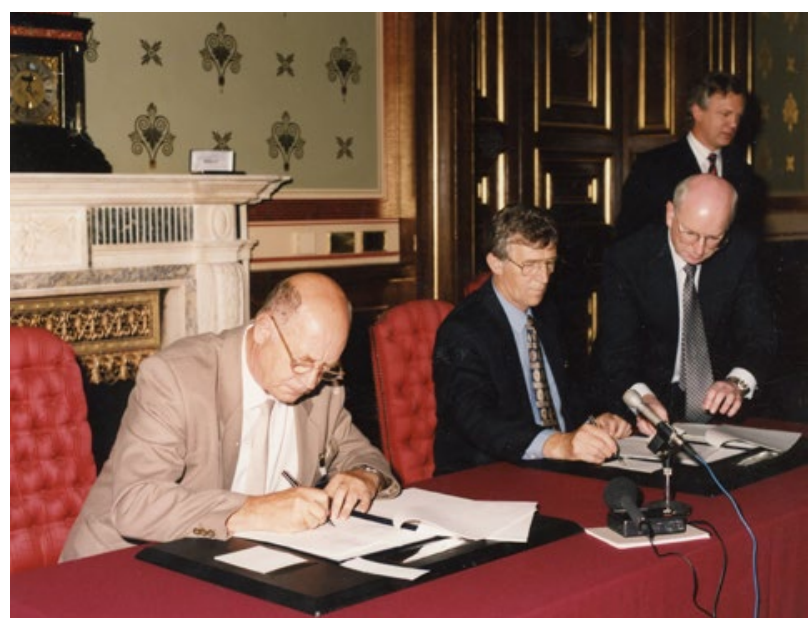

Photo 13. The signing of the Memorandum between the British Antarctic Survey (right-B. Heywood, Survey Director) and the Center for Antarctic Research of the NAS of Ukraine (left - P.F. Gozhik, Center Director) as a part of the Intergovernmental Agreement on the Transfer of the "Faraday" Antarctic Station. July 20; 1995.

Center of the Ministry of Education and Science of Ukraine. Academician P.F. Gozhik founded the scientific school of Ukrainian research geologists of Antarctica, and at the IGS of the NAS of Ukraine he set up a specialized subunit - the laboratory of Antarctic geoecology, which in 2004 was reorganized into the Department of Antarctic Geology and Geoecology. The department produced databases of geomorphological satellite information, compiled maps of the West Antarctic region, studied chemical geoecology, glaceochemistry, and biogeochemistry of Antarctica, and also studied chemical reactions on the surface of snow cover, the presence of halogenated hydrocarbons and heavy metals in the geological environment, performed a number of unique experiments addressing physico-chemical processes of snow and ice cover interaction with the atmosphere Gozhik, 2004; Gozhyk. et al., 2010, Arndt et al., 2013). One of the results of these studies was the publication of a unique Atlas of the Antarctic's deep structure, based on the gravimetric tomography data by Greku R. Kh., Gozhik P. F., Litvinov V. A., Usenko V. P., Greku T. R.: "Atlas of the Antarctic Deep Structure with the Gravimetric Tomography" (Greku et al., 2011).

The main result of P. F. Gozhik's Antarctic scientific and organizational activities, which lasted for nearly 40 years, can be described in his own words said on February 8, 2011, at the briefing to mark the 15th anniversary of the "Academician Vernadsky" Ukrainian Antarctic Station: "Ukraine

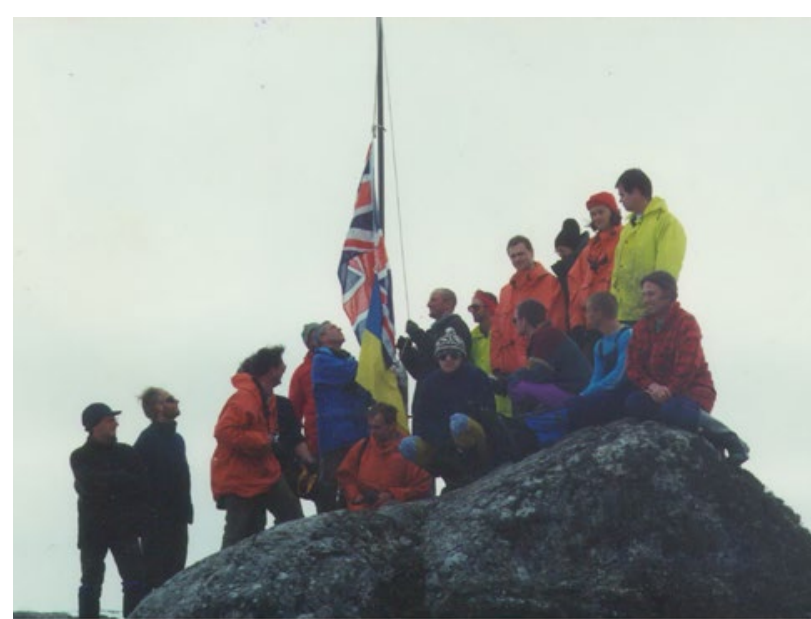

Photo 14. Ceremonial lowering the state flag of Great Britain and raising the state flag of Ukraine, which marked the inauguration of the "Academician Vernadsky" Antarctic Station. February 6, 1996.

has taken its place as an Antarctic state. Every year, Ukraine is expanding its presence in Antarctica... as, unfortunately, there are not so many fields in which Ukraine would match the level of advanced, high-tech states."

Indeed, thanks to its presence in Antarctca and the research at the "Academician Vernadsky" Station, Ukraine has joined the elite club of 26 countries that have the right to vote in determining the rules of work, research areas, etc., and the "Academician Vernadsky" Station itself has become one of the 17 base stations for the Earth's climate observation. P. F. Gozhik was sincerely proud of the result achieved; however, he belonged to the rare group of people to whom the work for the sake of science per se was more important than their own positions in science. Despite his great efforts to organize research in Antarctica, he never visited the "Academician Vernadsky" Station, as he considered it his duty to optimize the costs of Antarctic expeditions and would not have permitted spending money on himself.

Indeed, thanks to its presence in Antarctica and the research at the "Academician Vernadsky" station, Ukraine has joined the elite club of 26 countries that have the right to vote in determining the rules of work, research areas, etc., and the "Academician Vernadsky" station itself has become one of the 17 base stations for the Earth's climate observation. P.F. Gozhik was sincerely proud of the achieved result; however, he belonged to the rare 
group of people to whom the work for the sake of science itself exceeded the importance of their own positions in science. Despite his great efforts to organize research in Antarctica, he had never visited the "Academician Vernadsky" station, as he considered it his duty to optimize the costs of Antarctic expeditions and would not allow spending money on himself.

\section{Paleontology and stratigraphy}

The scientific interests of P. F. Gozhik were diverse, but, primarily, he was a renowned researcher of fossil freshwater mollusks from the Neogene-Quaternary deposits of the south of Eastern Europe. He covered this subject in numerous scientific articles and three monographs: "Freshwater and terrestrial mollusks of the Miocene of Right-bank Ukraine" (1978), "Pontian freshwater mollusks of the south of Ukraine and Moldova" (2002), "Freshwater mollusks of the late Cenozoic of the south of Eastern Europe" $(2006,2007)$. P. F. Gozhik identified and described two new genera, four new subgenera, and 59 new species. The monographic description of freshwater mollusks from the Upper Cenozoic sediments became a significant contribution to the history of their fauna and a reliable criterion for the correlation of the marine and continental rocks. As the leading expert on freshwater mollusks, he made a significant contribution to studying them not only in Ukraine, but in Moldova and Serbia as well. Studying the evidence from the Meotian deposits of Serbia allowed establishing a new genus of anodontides, which had been previously erroneously referred to unionids (Gozhik et al., 2007).

In 2012, a new edition of the Stratigraphic Code of Ukraine (Gozhyk, ed., 2012) was prepared and published under the guidance of Academician P.F. Gozhik. Although the first page stated that it was the second edition, in fact, it was a new development created in accordance with current trends of world science, taking into account its latest achievements and international standards for stratigraphic nomenclature, terminology, classification, and the identification procedure for stratons of different ranks (Gozhyk et al., 2011).

In recent years, under his leadership and with his direct participation, a methodology was developed for constructing stratigraphic schemes of oil and gas provinces of Ukraine. With reliance on fundamentally new conceptual principles and doctrines, the first-ever Meso-Cenozoic stratigraphic scheme of the Azov-Black Sea region was created
(Gozhik et al., 2006). An interregional correlation scheme of the Neogene deposits of Central and Eastern Paratethys of Ukraine was developed; the Quaternary stratigraphic scheme of Ukraine was produced and the first volume of the fundamental book "Stratigraphy of the Upper Proterozoic and Phanerozoic of Ukraine" was published (Gozhyk, 2013).

A significant part of P. F. Gozhik's activities was related with the leadership of the Ukrainian Paleontological Society, founded by Academician O.S. Vyalov in 1977 (Gozhik P. F. (ed.), 2007; Gozhik P. F., 2006). The energy and enthusiasm of P.F. Gozhik, and not infrequently also his own funds, granted the Ukrainian paleontological community the opportunity to hold annual sessions of the Society, exchange the latest research results, as well as improve their professional competence.

He was twice awarded the State Prize of Ukraine in Science and Technology: in 1989 - for the publication "Geology of the UkrSSR shelf" in eight volumes (1981-1987), and in 2000 - for the series of works "Regional oceanology: the state of the environment and mineral raw materials of the Atlantic, Indian, Southern Oceans and their seas".

P.F. Gozhik authored more than 400 scientific publications, particularly, numerous monographs including "Freshwater and terrestrial mollusks of the Miocene of Right-bank Ukraine" (1978), "Anthropogene deposits of Ukraine" (1986), "Geology and metallogeny of the southwestern Red Sea" (1988), "Geological conditions of construction of the Dnieper - Bug hydroelectric power plant" (1989), "Geology and metallogeny of the Southern Ocean" (1991), "Geological structure of the northern Black Sea" (1995), "Geological and geomorphological studies of the eastern Antarctic seas of the Southern Ocean" (2002), "Pontian freshwater mollusks of southern Ukraine and Moldova" (2002), "Freshwater mollusks of the late Cenozoic of the south of Eastern Europe" (2006, 2007) and "Stratigraphy of Meso-Cenozoic sediments of the northwestern shelf of the Black Sea" (2006). He also contributed to a series of collaborative monographs on oil and gas issues in Ukraine (Chebanenko et al., 2005, Gozhik et al., 2006).

The studies of P. F. Gozhik are well known abroad (Galetskyi et al., 2007; Velikanov et al., 2006; Gurov, Gozhik, 2006). His scientific articles were published in the United States, Great Britain, Bulgaria, Poland, and Austria. He presented 
scientific papers at international conferences and symposia all around the world. He was a member of the International Union for Quaternary Research (INQUA). The Polish Geological Society elected him its honorary member.

P. F. Gozhik combined intense scientific work with pedagogical and organizational duties. He lectured at Taras Shevchenko National University of Kyiv; he also supervized more than a dozen of doctors and candidates of sciences.

P. F. Gozhik was also active in public life. In the late 1990s he was one of the founders of the "Chysta Hvylia" (Ukr. for Clear Wave) public organization; in the 2000s he participated as an expert in the all-Ukrainian project "Seven Wonders of Ukraine", which contributed to the development of national natural history and local lore.

Long before the "amber fever", which has recently spread to Volhyn Polissya, the IGS of the NAS of Ukraine conducted research concerning the rational development of mineral resources in this region. Through P. F. Gozhyk's initiative a series of "Amber World" conferences were held and several models of the integral development of placer deposits were proposed (Gozhyk, ed., 2008).

P.F. Gozhik's work in science administration was also extremely active. Under his leadership, the Department of Earth Sciences of the NAS of Ukraine effectively investigated raw minerals, running "Minerals of Ukraine" targeted program of applied research in 2012-2016, and in 2017 launching the program "Development of geological, geophysical sciences, technologies and upbuilding of mineral resources in Ukraine and the study, forecasting, and minimization of emergencies". P. F. Gozhik and his team made a significant contribution to the Department's work aimed at reengagement of marine research within the targeted multidisciplinary research programs of the NAS of Ukraine, such as "Multidisciplinary bioresource, hydrophysical as well as geological and geophysical studies of the marine environment, promising oil and gas structures and mapping the distribution of gas hydrates in the Black Sea and the Sea of Azov" (2007-2009) and "Integral assessment and forecasting of the marine environment and resource dynamics of the Azov-Black Sea Basin" (2010-2012).

Professor P. F. Gozhik was the chairman of the IGS specialized council for theses defense in 04.00.09 specialization - paleontology and stratigraphy; he was also a member of the specialized council for theses defense in 04.00.10 specialization - geology of the seas and oceans.

He was the head of the National Stratigraphic Committee of Ukraine, the President of the Paleontological Society, a member of the Scientific and Technological Council for Antarctic Research, a member of the NAS Commission for Academician V. I. Vernadsky's Scientific Heritage, the chairman of the section of the Committee for State Prizes of Ukraine in Science and Technology, a member of the Scientific and Technological Council of the Ministry of Environment, a member of the Scientific and Technological Council of Derzhgeonadra. Behind this notable list of positions taken lies an immense number of duties and amount of systematic daily work, along with a huge burden of responsibility (photo 15).

Academician P.F. Gozhik gave a lot of attention to editing scientific articles, monographs, collections of scientific works. He was the editor-in-chief of "Geological Journal", "Ukrainian Antarctic Journal", "The Collection of Scientific Papers of the NAS Institute of Geological Sciences", the deputy chief editor of "Paleontological Collection", a member of the editorial board of the Polish journal "Studia Quaternaria", "Geology and minerals of the World Ocean", "Stratigraphy and sedimentology of oilgas basins", "Mineral resources of Ukraine", "The Reports of the NAS of Ukraine" etc.

P. F. Gozhik was a member of the International Union for Quaternary Research (INQUA) (photo 13). The Polish Geological Society elected him its honorary member, and at the end of the year 2020 ,

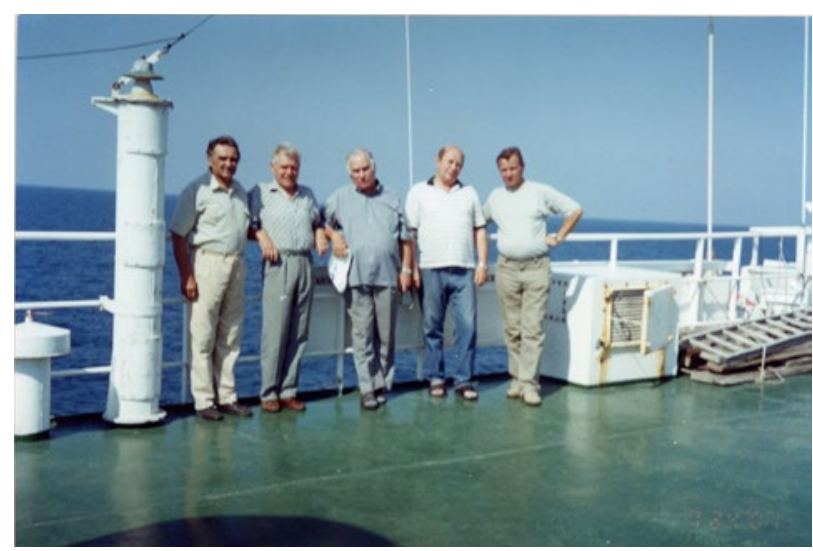

Photo 15. Organizers of and performers in the Black Sea multidisciplinary research on the deck of "Professor Vodianytsky" research vessel (from left to right): S. O. Kleshchenko, V.I. Starostenko, E. F. Shnyukov, P. F. Gozhik, V.P. Kobolev. 
NAS Academician P.F. Gozhik was nominated to be elected a foreign member of the Polish Academy of Art and Science (Polska Akademia Umiejętności). A letter of condolence from Professor TadeuszMarek Perit, a foreign member of the NAS of Ukraine, read: "My sorrow was deep also because I have been one of the proposers to appoint Professor Gozhik a foreign member of the Polish Academy of Arts and Letters, and the nomination met the enthusiastic support of all the members of the Division IV (Natural Sciences). Very regrettably, we will not meet with him on the occasion of his official, gala appointment..."

The geological community and the Ukrainian government highly praised the contribution of P. F. Gozhik to the development of national geology. He earned the title of a Merited Figure of Science and Technology (1997), won two State Prizes of Ukraine in Science and Technology $(1989,2000)$

\section{REFERENCES}

Arndt J.E., Schenke H.W., Jakobsson M. N., Nitsche F. O., Buys G. G., Goleby B., Rebesco M., Bohoyo F., Hong J. K., Black J., Greku R. Kh., Udintsev G. B., Barrios F., Reynoso-Peralta W., Taisei M., Wigley R., 2013. The International Bathymetric Chart of the Southern Ocean (IBCSO) Version 1.0. Pangaea. Doi: 10.1594/PAN-GAEA.805736.

Chebanenko I. I., Gozhik P. F., Krayushkin V.A. et al., 2005. Petroleum in the basement of sedimentary basins. Kiev: EKMO. $255 \mathrm{p}$.

Galetskyi L. S., Cherniyenko N. M., Akulov M. O., Baisarovych M. M., Gozhik P. F. et al., 2007. Atlas of the geology and mineral deposits of Ukraine. Toronto: University of Toronto Press. $168 \mathrm{p}$.

Garkusha N.A., Gozhik P.F. (eds), 1984. Geology of the shelf of the Ukrainian SSR. Limans (Estuary-Lagoon). Kyiv: Naukova Dumka. 176 p. (In Russian).

Gozhik P. F. (ed.), 2000. The Map of Quaternary Formation of Ukraine, scale 1:1000 000. Kyiv: State Geol. Serv.

Gozhik P.F. (ed.), 2007. Paleontological research in Ukraine: history, current status and prospects. Coll. Sci. Papers. Institute of Geological Sciences of the National Academy of Sciences of Ukraine. Kyiv: Nora-print. 559 p. (In Ukrainian).

Gozhik P.F. 2004. Main climatic changes in the Quaternary of Poland, Belarus and Ukraine. Abstract of the international Field Symposium on Quaternary Geology and Modem Terrestrial processes, Western Latvia, September 12-17. Riga. pp. 36-38.

Gozhik P. F. et al., 1991. Shnyukov E. F. (ed.) Geology and metallogeny of the Southern Ocean. Kiev: Naukova Dumka. 190 p. (In Russian).

Gozhik P. F., 2002. Pontic freshwater mollusks of the south of Ukraine and Moldova. Kyiv. Pp. 98 (In Ukrainian). and P.A. Tutkovsky Prize of the National Academy of Sciences of Ukraine (2008), he was honored with the Order "For Merits" III and II Class (2008, 2012), the Diploma of the Verkhovna Rada of Ukraine, V. I. Luchytsky medal "For Merits in Subsoil Exploration" (1998), the Gold Medal of Ukraine's Geologists Union and with numerous departmental awards. In February 2021, on the occasion of the "Academician Vernadsky" Antarctic Station's 25th anniversary, P.F. Gozhik was posthumously awarded with the Order of Prince Yaroslav the Wise V Class.

We believe that the future generations of researchers and experts in Earth sciences will inherit and further develop the ideas of P.F. Gozhik - the outstanding scientist whose name deservedly went down in the history of science. His life is a vivid example of how one should work to create the future of one's country.

Arndt J. E., Schenke H. W., Jakobsson M. N., Nitsche F. O., Buys G. G., Goleby B., Rebesco M., Bohoyo F., Hong J. K., Black J., Greku R. Kh., Udintsev G. B., Barrios F., Reynoso-Peralta W., Taisei M., Wigley R. The International Bathymetric Chart of the Southern Ocean (IBCSO) Version 1.0. Pangaea. 2013. Doi: 10.1594/PAN-GAEA.805736.

Chebanenko I. I., Gozhik P. F., Krayushkin V.A. et al. Petroleum in the basement of sedimentary basins. Kiev: EKMO, 2005. $255 \mathrm{p}$.

Galetskyi L. S., Cherniyenko N. M., Akulov M. O., Baisarovych M. M., Gozhik P. F. et al. Atlas of the geology and mineral deposits of Ukraine. Toronto: University of Toronto Press, 2007. 168 p.

Гаркуша Н.А., Гожик П.Ф (отв. реА.) Геология шельфа УССР. Аиманы. Київ: Наукова Аумка, 1984. 176 с.

Gozhik P.F. (ed.) The Map of Quaternary Formation of Ukraine, scale 1:1000 000. Kyiv: State Geol. Serv., 2000.

Гожик П. Ф. (реА.) Палеонтологічні досліАження в Україні: історія, сучасний стан та перспективи: зб. наук. пр. Ін-ту геол. наук НАН України. К.: Нора-принт, 2007. 559 с.

Gozhik P.F. Main climatic changes in the Quaternary of Poland, Belarus and Ukraine. Abstract of the international Field Symposium on Quaternary Geology and Modem Terrestrial processes, Western Latwia, September 12-17, 2004. Riga, 2004. № 48. pp. 36-38.

Гожик П. Ф. и Ар.; отв. реА. Шнюков Е. Ф. Геология и метал^огения Южного океана. Київ: Наукова Аумка, 1991. 190 с.

Гожик П. Ф. Понтичні прісноводні Молюски півАня України і Молдови. Київ, 2002. 98 с. 
Gozhik P. F., 2004. Ukrainian research of Antarctica in terms of the third International Polar Year Ukraine: geographical problems of sustainable development, Vol. 1, Pp. 227-235. (In Ukrainian).

Gozhik P.F., 2006. Freshwater mollusks of the Late Cenozoic of the south of Eastern Europe. Vol. 1. Superfamily UNIONOIDEA. Kyiv. 280 p. (In Russian).

Gozhik P. F., 2006. To the 30th anniversary of the Ukrainian Paleontological Society. Paleontological research in Ukraine: history, current status and prospects. Kyiv. Pp. 17-26. (In Ukrainian).

Gozhik P.F., Chebanenko I. I., Krayushkin V.O. et al., 2006. Oi and gas prospects of Ukraine: scientific and practical bases of hydrocarbon exploration in the Sea of Azov. Kyiv: EKMO. 339 p. (In Ukrainian).

Gozhik P. F., Chugunny Yu., Melnik V. et al., 1976. Guide to VIII Int. Symp. on loessial rocks. Kyiv. 48 p. (In Russian).

Gozhik P.F., Datsenko L. N., 2007. Freshwater mollusks of the Late Cenozoic in the south of Eastern Europe. Vol. 2. Families Sphaeridae, Pisidiidae, Corbiculoidae, Neritidae, Viviparidae, Valvatidae, Bithyniidae, Lithoglyphidae, Melanopsidae. Kyiv. 253 p. (In Russian).

Gozhik P. F., Maslun N. V., Plotnikova L. F., Ivanik M. M., Yakushin L. M., Ishchenko I. I., 2006. Stratigraphy of Mesocainozoic deposits of the north-western shelf of the Black Sea. Kyiv: Logos. 171 p. (In Ukrainian).

Gozhik P. F., Mitin L. I., 1984. Antarctic round-the-world expedition. Geological journal, no. 4, pp. 138-139. (In Russian).

Gozhik P. F., Mitropol'skiy A. Yu., Shcherbakov I. B. et al., 1988. Geology and metallogeny of the southwestern part of the Red Sea. Kyiv: Naukova Dumka. 160 p. (In Russian).

Gozhik P. F., Novoselsky F.A., 1989. Geological conditions for the construction of the Dnieper-Bug hydroelectric complex. Kyiv: Naukova Dumka. 118 p. (In Russian).

Gozhik P.F., Prisyazhnyuk V.A., 1978. Freshwater and terrestrial mollusks of the Miocene of the Right-Bank Ukraine. Kyiv: Naukova Dumka. 173 p. (In Russian).

Gozhik P. F., Shelkoplyas V. N., Khristoforova T., 1995. Development Stages of Loessial and Glacial Formations in Ukraine (Stratigraphy of Loesses in Ukraine). Annales Universitatis Mariae Curie-Sklodowska. Vol. 4. Pp 65-74.

Gozhik P. F., Shelkoplyas V. N., Komar M.S., Matviishina Z. M., Perederiy V. I. Putivnik X Polsko-Ukrainsky seminar "Korelatsiya lesiv i ledovikovykh vidkladiv Polshi i Ukraini”. Kyiv, 2000. Pp. 34.

Gozhyk P. F. (ed.), 2008. Ukrainian Amber World: Proc. II Int. Sci. Conf. (Oct. 17-212007, Kyiv-Rivne). Kyiv. 172 p. (In Ukrainian).

Gozhyk P. F. (ed.)., 2013. Stratigraphy of Upper Proterozoic and Phanerozoic of Ukraine. Vol. 1: Stratigraphy of Upper Proterozoic, Paleozoic and Mesozoic of Ukraine. Kyiv: Logos. 638 p. (In Ukrainian).

Gozhyk P. F., Litvinov V., Malanchuk V. M. 2010. Scientific activity of Ukraine in Antarctica in the next decade. Ukrainian
Гожик П. Ф. АосліАження України в Антарктиці в плані провеАення третього Міжнародного полярного року. Україна: географічні проблеми сталого розвитку. 2004. Т. 1. С. 227-235.

Гожик П. Ф. Пресноводные момююски позАнего кайнозоя юга Восточной Европы: в 2-х ч.: ч. 1. НаАсемейство UNIONOIDEA. Київ, 2006. 280 с.

Гожик П. Ф. Ао 30-річчя Українського палеонтологічного товариства. Палеонтологічні дослідження в Україні: історія, сучасний стан та перспективи. Київ, 2006. с. 17-26.

Гожик П.Ф., Чебаненко І.І., Краюшкін В.О. та ін. Нафтогазоперспективні об'єкти України: наукові та практичні основи пошуків вуглеводнів в Азовському морі. Київ: EKMO, 2006. 339 c.

Гожик П.Ф., Чугунный Ю.Г., Мельник В.Н. и Ар. Путеводитель VIII Международного симпозиума по лессовым породам (Киев-ОАесса, 4-12 окт. 1976 г.). Киев, 1976. 48 с.

Гожик П. Ф., Ааценко А.Н. Пресноводные момлюски позАнего кайнозоя юга Восточной Европы. в 2-х ч.: моногр. 4. 2. Семейства Sphaeridae, Pisidiidae, Corbiculoidae, Neritidae, Viviparidae, Valvatidae, Bithyniidae, Lithoglyphidae, Melanopsidae. Київ, 2007. 253 с.

Гожик П. Ф., Маслун Н.В., Плотнікова А. Ф., Іванік М. М., Якушин ^.М., Іщенко І.І. Стратиграфія мезокайнозойських відкладів північно-західного шельфу Чорного моря. Київ: ^огос, 2006. $171 \mathrm{c}$.

Гожик П. Ф., Митин А. И. Кругосветная антарктическая экспедиция. Геологічний журнал. 1984. № 4. С. 138-139.

Гожик П. Ф., Митропольский А. Ю., Щербаков И. Б. и Ар. Геология и метаммогения юго-западной части Красного моря. Київ: Наук. Аумка, 1988. 160 с.

Гожик П. Ф., Новосельский Ф.А. Геологические условия строительства Анепровско-Бугского гилроузла. Київ: Наук. Аумка, 1989. $118 \mathrm{c.}$

Гожик П.Ф., Присяжнюк В.А. Пресноводные и наземные моммюски миоцена Правобережной Украины. Київ: Наук. Аумка, 1978. 173 с.

Gozhik P. F., Shelkoplyas V. N., Khristoforova T. Development Stages of Loessial and Glacial Formations in Ukraine (Stratigraphy of Loesses in Ukraine). Annales Universitatis Mariae Curie-Sklodowska. Lublin, Polonia, 1995. Vol. 4. Pp 65-74.

Гожик П. Ф., Шовкопляс В. М., Комар М. С. та ін. Путівник: Х польсько-український семінар "Кореляція лесів і ^ьодовикових відклаАів Польщі і України", 11-16 верес. 2000 р. Kyiv, 2000. 34 c.

Гожик П. Ф. (реА.). Український бурштин: матеріали I міжнар. наук.-практ. конф. “Український бурштиновий світ", 17-21 жовт. 2007 р., Київ, 2008. 172 с.

Гожик П. Ф. (реА.) Стратиграфія верхнього протерозою та фанерозою України: [у 2 т.] Т. 1: Стратиграфія верхнього протерозою, палеозою та мезозою України. Київ, 2013. 638 с.

Гожик П. Ф., Аитвинов В.А., Маланчук В. М. Наукова Аіяльність України в Антарктиці за десятирічний періоА. 
Antarctic Journal, no. 9, Pp. 7-15. Doi: 10.33275/17277485.9.2010.387 (In Ukrainian).

Gozhyk, P.F. (ed.), 2012. Stratigraphic Code of Ukraine. Kyiv: Logos. 66 p. (In Ukrainian).

Gozhyk, P.F., Konstantynenko L. I., Poletaev V. I., 2011. The modernization of the Phanerozoic stratigraphic charts of Ukraine: modern position, problems and the ways of their decision. Geological journal (Ukraine). No. 1, Pp. 7-13. Doi: 10.30836/igs.1025-6814.2011.1.139061. (In Ukrainian).

Greku R., Gozhik P., Litvinov V., Usenko V., Greku T., 2009. Atlas of the Antarctic Deep Structure with the Gravimetric Tomography. Kiev.

Gurov E. P., Gozhik P. F., 2006. Impact Cratering in the Earth's History. Kyiv. 218 p. (In Russian).

Ivanik O. M., Gozhik P. F., 2004. Geological and geomophological studies of the eastern Antarctic seas of the Southern Ocean. Kyiv. 144 p. (In Ukrainian).

Lindner L., Bogutsky A., Gozhik P., Marks L., Łanczont M., Wojtanowicz J., 2006. Correlation of Pleistocene deposits in the area between Baltic and Black Sea, Central Europe. Geological Quarterly. Vol. 5, no 1. Pp. 195-210.

Lindner L., Bogutsky A., Gozhik Pet al., 2005. Przekroj geologiczny przez osady plejstocenskie miedzymorza BaltyckoCzarnomorskiego oraz jego znaczenie w badaniach nad Czwartorzedem Europy. Glacial and periglacial of Volyn Polissya. Lviv: Ivan Franko Lviv National University Publishing Center. Pp. 87-93. (In Poland).

Moroz S. A., Sulimov I. N., Gozhik P. F., 1995. Geological structure of the Northern Black Sea region. Kyiv: Naukova Dumka, 183 p. (In Russian).

Ponomarenko O. M., Mitropolsky O. Yu., Shekhunova S. B., 2017. With geology in heart (to the 80th anniversary of Academician of NAS of Ukraine P. F. Gozhik). Visnyk of the National Academy of Sciences of Ukraine, no 10, Pp. 95-101. (In Ukrainian).

Shelkoplyas V. N., Gozhik P. F., Khristoforova T.F. et al., 1986. Anthropogenic deposits of Ukraine. Kyiv: Naukova Dumka. 150 p. (In Russian).

Velikanov V.Y., Gurskiy D.S., Gozhik P. F. et al., 2006. Lithosphere of Ukraine: Atlas. Kyiv: Geografika. 66 p. (In Ukrainian).
Український антарктичний журнал. 2010. № 9. C. 7-15. Doi: 10.33275/1727-7485.9.2010.387.

Гожик П. Ф. (реА.) Стратиграфічний кодекс України. К.: ^огос, 2012. 66 c.

Гожик П. Ф., Константиненко А. І., Полєтаєв В.ІІ. Модернізація стратиграфічних схем фанерозою України: сучасний стан, проблеми і шляхи їх вирішення. Геологічний журнал. 2011. № 1. c. 7-13. Doi: 10.30836/igs.1025-6814.2011.1.139061.

Greku R., Gozhik P., Litvinov V., Usenko V., Greku T. Atlas of the Antarctic Deep Structure with the Gravimetric Tomography. Kiev, 2009.

Гуров Е.П., Гожик П. Ф. Импактное кратерообразование в истории Земли. Киев, 2006. 218 с.

Іванік О. М., Гожик П. Ф. Геолого-геомофологічні досліАження схіАноантарктичних морів ПівАенного океану. Київ, 2002. $143 \mathrm{c}$.

Lindner L., Bogutsky A., Gozhik P., Marks L., Łanczont M., Wojtanowicz J. Correlation of Pleistocene deposits in the area between Baltic and Black Sea, Central Europe. Geological Quarterly. 2006. Vol. 5, no 1. Pp. 195-210.

Lindner L., Bogutsky A., Gozhik Pet al. Przekroj geologiczny przez osady plejstocenskie miedzymorza Baltycko-Czarnomorskiego oraz jego znaczenie w badaniach nad Czwartorzedem Europy. Гляціал і перигляціал Волинського Полісся. Аьвів: ВиА. центр $\Lambda$ НУ ім. І. Франка, 2005. с. 87-93.

Мороз С.А., Сулимов И. Н., Гожик П. Ф. Геологическое строение Северного Черноморья. Київ: Наукова Аумка, 1995. $183 \mathrm{c}$.

Пономаренко О.М., Митропольський О. Ю., Шехунова С. Б. 3 геологією у серці (Ао 80-річчя акалеміка НАН України П. Ф. Гожика). Вісник НАН України. 2017. № 10. С. 95-101.

Шелкопляс В. Н., Гожик П. Ф., Христофорова Т. Ф. и Ар. Антропогеновые отложения Украины. К.: Наук. Аумка, 1986. $150 \mathrm{c}$.

Веліканов В.Я., Гурський А. С., Гожик П. Ф. та ін. Літосфера України: Атлас. К.: ТОВ «Географіка", 2006. 66 с.
Manuscript received February 26, 2021; revision accepted April 12, 2021.
Інститут геологічних наук НАН України, Київ, Україна 